\title{
FACTORS INFLUENCING STUDENT CHOICE IN HIGHER EDUCATION
}

\author{
Rasa Grigolien $\dot{e}^{1,2}$, Raimonda Tamoševičiene $\dot{\mathrm{e}}^{\mathbf{1}}$ \\ ${ }^{1}$ Lithuania Business University of Applied Sciences, ${ }^{2}$ Klaipéda University
}

\begin{abstract}
Increasing global competition, globalisation of markets and the global economic downturn encourages the search of ways to maintain the stability and growth of industrial enterprises. Nowadays, when business environment is rapidly changing, enterprises have to increase constantly their competitive advantage. Human resources are crucial in addressing these issues. Motives of human behaviour energy and direct it to a certain direction. Needs, preferences, and interests are by far the strongest reasons for choosing the path of further learning. This article seeks to answer how motivation influences young people to choose a profession and what factors are the most important in this choosing. On the one hand, motivation has explained under structural point of view as a factor or set of reasons. On the other hand, motivation has interpreted as a dynamic phenomenon, process, and mechanism. Development of industrial psychology and especially behaviourism made very big influence on the development of psychological motivation theories since 1990. The field investigation of this psychology is the subject of human behaviour in the choosing of the studies. One or another treatment is depending on environmental conditions. A survey reveals that in order to motivate a person, it is necessary to enable them to meet theirs basic needs in such a way that helps achieving the objectives of all institution. The article also presents the most important criteria influencing the choice and their relative weight. The results of the research carried out by the authors have compared with the results of similar investigations by other authors. There are focused on the main factors encouraging choosing particular higher education institution and studies at it. Based on the results of the research, it was made these conclusions. A survey showed that two factors are most important when students are choosing to study. These factors are the desire to acquire higher education and the desired specialty, as well as the personal desire to develop, expand knowledge, achieve the goal. $57 \%$ of respondents indicated that opinions of parents, relatives, friends or teachers were not relevant to them. When it comes to choosing a higher education institution, the most important are the city were person wants to study and where the institution is located, higher education institution prestige and quality of the studies.

KEY WORDS: higher education; student choice; motives for studies; choosing of studies; factors influencing choice.
\end{abstract}

\section{Introduction}

Today's rapidly changing world of labour market is creating new challenges that are more challenging for young people who are joining it. To meet the changed globalised structures there is a need of well-educated researchers, engineers, technicians and other professionals with innovative ideas and the capacity to solve problems, i.e. meet challenges from the megatrends (Bjurulf, 2012). In order to become successful players in the work market, young people must not only meet certain professional criteria that are as relevant as their own, but also have certain personal competences.

When it comes to modern higher education, it is very important to mention creativity. This is one of the most important competencies. It must develop in young people nowadays. The successful implementation of creativity in education is largely dependent on teachers' own beliefs about creativity. In recent years, creativity has been widely investigated at all levels of education, higher education including (Bereczkia, Kárpátib, 2018; Burkšaitienè, 2018).

Education and training institutions implement life skills development programs, the aim of which is to help learners adapt to society and behave in a positive, effective way to cope with the needs and problems of everyday life. Life skills have defined as the ability to adapt to society and behave positively, the ability of individuals to deal effectively with the needs and challenges of everyday life. These are abilities, which help young people maintain mental health and self- confidence when confronted with the realities of life (Gudžinskienè, Railienè, 2012).

Naturally, when choosing their own way of life, young people are aware of the career challenges that high quality basic education in high school is of particular importance to a successful start. In addition, it is very important for a higher education institution not only to guarantee high quality studies, to maintain the high school's prestige, competitiveness, but also to meet the expectations of the candidate for studies as well.

Recently, when analysing the criteria for choosing a higher education institution, it is necessary to talk about the country from which the student came. Some criteria may be important for an applicant from Lithuania and quite others for an applicant from a foreign country. Empowering global education is seen as a trend in many developing countries. The borderless education not only show the tendency of students in pursuing higher education abroad for the purpose of obtaining a better quality education, but it is also become a main source that generate revenue for university (Jupiter, Othman, Suki et al, 2017). It was founded that the main motivations of students who choose to study at foreign countries are different to those students who choose to study at home universities (Wilkins, Balakrishnan, Huisman, 2012).

However, there is also a lot of research why young people choose one or another higher education institution in the native country. Quite often, students' choices are influenced by perceptions of the value of education, which are influenced by differences in costs (monetary and non-monetary), students' attitudes, and socio- 
demographic characteristics (Petruzzellis, Romanazzi, 2010). The other research findings showed that one of the reason that made the respondents choose to study at university is its reputation. This reason was rated the highest level (Kirahat, Burananuth, 2018).

There have also been a number of researches as to why good candidates for mathematics or physics may choose to study at a university outside STEM (science, technology, engineering, mathematics) subjects. It may probably be argued that psychoanalytic interpretations are also important in analysing the reasons for choice. Consequently, the influence of unconscious forces on young people's decision-making must also be assessed (Rodd, Reiss, Mujtaba, 2014).

The high schools ask students to answer the question what are the main criteria for choosing high school. How many coming young people are motivated not only to study seriously according to the chosen study program, but how much are they prepared for systematic studies in higher education in general and what are their main goal. Do they come not only for a good time to spend and get a higher education diploma?

Monitoring graduates also helps answer these questions. Monitoring graduates also helps answer these questions. Their observations and comments are very important for the higher school in improving the quality of studies and increasing its prestige in society (Romeryte-Šereikienè, Šaltytè-Vaisiauskè, 2019).

Research problem. Wide discussion about criteria that makes young people choose one or other study program or institution, watching disproportionately distribution between same level study programs that makes a person question about chosen career, how these criteria change? Lithuania Business University of Applied Sciences students had chosen to answer these questions.

Research object. Criteria that has influence in choice of studies.

The aim. To identify the most important criteria that has influence in choosing of studies and higher education insitution.

The following tasks are set to achieve this aim:

1. To determine the most important criteria influencing the choice of a higher education institution.

2. To evaluate the motives of college students in choosing studies.

3. To compare the obtained research results with the results of similar research in Lithuania and other countries.

Research methods. Methods used in the research: literature and document analysis, systematisation, quantitative survey: a questionnaire of criteria for studies choosing, statistical data analysis and interpretation of quantitative research.

\section{Research of criteria in choosing studies}

The field of education is increasingly being identified by society as a priority, a key element that often plays a decisive role in the successful development of the state and society. Therefore, the demands placed on educational establishments at all levels by society are particularly high. Each education sector's institution is under pressure from the society, it strives to meet the expectations of both: the society and institution clients by providing quality, innovative, interactive education services in particular. Graduates are under society pressure to choose between university and college institutions when they are choosing to study at a higher education institution. They must to take into account criteria such as quality of studies, employability, personal or parents', friends' interest and expectations. Although family and cultural factors have been assumed to play important roles in the career development, theory-driven research on this topic remains limited (Hui, Lent, 2018). Marketing activities carried out by higher education institutions in order to attract students also play a key role in the choice of studies.

Students learning success and response to successful job are determent by these: successful profession choice, academic learning and results, career development (Katkonienè, Ustinavičiūtè, Žemaitaitytè, 2011). Vocational persons choice have connected with deliberate choice, purpose to find and ensure a place in work market and in social environment. The representatives of Generation Y (also known as Millennials, Generation "Me") had described as individualists, seeking for attention, skilfully mastering technologies, and looking for a meaningful activity (Statnickè, Čeledinaitè, 2018). In addition, vocational decision and choice shows a personal growth and expansion that leads person's characteristics, maturity, intelligence, interests, inclination, talents, strategic thinking, etc. We can indicate that in choosing of profession the most important three criteria are: 1 . I can - personal peculiarity, health position, talents, learning outcomes; 2. I want - if profession going to give satisfaction, would give inclination, interests; 3. I need - economic needs and prospects, public service (Liobikienè, Bukauskienè, 2014).

Choice in studies makes an influence on a young person. It is and values and personal needs and society, public environment which opens possibilities. The study choice motives forms by factors like information, opinions, values that are led by society, this is said by sociological analysis authors V. Leonavičius and A. Rutkienè (2010, p. 54). Position "where they going to take me in, there I'm going to study" itself can have bad consequence in professional life and it will make society expectations unsatisfied. That is why profession and career path choice are, said by L. Jovaiša (2009), multiply act, long-lasting process and studies choice is complex thing: while choosing study program person not only needs to know what profession they want but they need to choose a place to study (city or even a country), choose higher education institution, assess their abilities, eligibility for one or other profession, also opportunities by school exams scores, also opportunities by the budget, if later on it has to be coordinated with studies (MOSTA, 2014, p. 3).

It also suggests that higher education students and undergraduate opinion polls have conducted in the Lithuanian higher education area about their motives for choosing a higher education institution and the study program they want to study. After reviewing 2008-2017 the results of the research carried out in Lithuania 
(LBUAS, 2008, 2012; MOSTA, 2014; LTVK 2015, 2016, 2017, 2018; LTVK ŠF, 2014, 2015; Urbonienè, 2015; Balevičiūtè, Valavičius, 2014; Liubinienè, Slimavičienè, 2016;) on student motivation and factors which influence the choice of a university and the program you want to study, it can be seen that the main trends are changing. The study commissioned by the Ministry of Education and Science of the Republic of Lithuania showed that the main factors determining the choice of a higher education institution and study program are: the need for a study program in the work market; clear career opportunities; good material conditions in the future; expressions (intellectual and artistic); study program is related to personal interests; The study program is related to the favourite subjects taught. 2012 The research carried out by UAB RAIT, commissioned by the Ministry of Education and Science of the Republic of Lithuania, has already shown that the main criteria for choosing which Lithuanian higher education institution and under which study program are to study were: the subject you want to study; employment prospect; the cost of studies and the public opinion on the higher education institution and the study program (2012, p. 8). Science and Research Analysis Center (MOSTA) in 2014. According to the data of the research of the higher education system stakeholders, the main factor determining the choice of the higher education institution is the aspect of study quality at that higher education institution. Attention has drawn to the fact that when students choose a high school, an important "study city" (mostly Vilnius capital), school prestige and quality of studies (MOSTA, 2014, p. 7). When choosing a study program and a specialty, it is important for students to relate to favorite and relevant subjects, "job security", "prospect for senior positions" and "free study place" (MOSTA, 2014, pp. 5-6). When choosing where to study - at a university or college - students are more likely to choose a college based on better practical training, a change in the society's view of college studies, the willingness to study according to the desired study program, and easier access to employment after completing college studies. The feedback and recommendations of senior course students and graduates (LTVK, 2015, 2016, 2017, and 2018) have a great influence on the choice of college studies and study program. Summarizing the research data, one can distinguish the main tendencies, what motives of young people determines the choice of the school of higher education and the study program: 1. the desire to study according to that specialty; 2. specialty prestige in society; Career opportunities; 4. realization of personal abilities; 5 . desire to obtain a higher education diploma. Higher schools, in order to attract as many candidates as possible to study, have to study the main motives and factors of study choices.

\section{Methodology of research}

A quantitative study has carried out using a questionnaire for the first year students of the Lithuanian Business College. Prepare a questionnaire to look at similar work done by interviewing students from other higher education institutions. The purpose of the survey was to find out what students expect during college studies and what are their main goals, what expectations and plans they can designate for the future. One of the questions was "Who influenced the choice of studies at the Lithuania Business University of Applied Sciences?" In the course of the research, the research object has chosen as a convenient population consisting of students of the first-year college of continuing education and fulltime studies. The study had carried out at a micro level, since the students study in one environment - the The study had carried out at a micro level in Klaipeda and Vilnius departments.

The study sample based on the Paniott formula (Kardelis, 2016):

$$
n=\frac{1}{\Delta^{2}+\frac{1}{N}}
$$

Herein $n$ - sample size, $\Delta$ - sampling error size. As this study examines the attitude of students, rather than certain quantitative parameters, the error can be increased up to $9 \%$, i.e. $\Delta=0.09, \mathrm{~N}-$ the size of the general population.

The sample size calculated according to formula (Eq. 1):

$$
n=\frac{1}{0.09^{2}+\frac{1}{145}}=66
$$

The questionnaire has filled by 67 first-year students; therefore, it can stated that the results of the study performed are validate. All returned questionnaires have filled in completely.

Respondents provided with an original questionnaire drawn up by the authors, which presents matrix questions of a closed type. Among other questions in the questionnaire, respondents asked to evaluate the following study selection criteria:

- Desire to pursue higher education;

- Personal desire to develop, expand knowledge, achieve the goal;

- Desire to obtain a higher education diploma;

- Desire to acquire a profession;

- Good career opportunities;

- Better opportunities and perspectives in the work market;

- Desire to find a job easier;

- Pragmatic circumstances, because it is closer to home, more convenient;

- Exam results;

- Random selection;

- $\quad$ Opportunity to study for free;

- Encouragement of family members (parents);

- Promotion of friends and acquaintances;

- Teacher counsel;

- Reluctance to dismiss parents;

- An attractive, interesting study program;

- Good study quality;

- The emergence of a new study program (specialization);

- A more positive attitude towards colleges, a better image, goodwill;

- Fashion. 
Each of these claims had to be evaluate using the following terms:

- Totally agree;

- I agree;

- Neither agree nor disagree;

- I disagree;

- I totally disagree.

The survey conducted online. An application to fill out a questionnaire sent to each respondent via e-mail. The purpose of the survey and usage of received data indicated in the letter. The anonymity of the respondents also ensured and the confidentiality principle maintained.

The results of the survey were grouped, systematized and visualized in diagrams and graphs.

\section{Results}

The institution in which the survey took place conducts studies in two cities of Lithuania: Vilnius and Klaipeda. This is a non-state higher education institution. As mentioned above, the first-courses of regular and parttime study forms of both departments surveyed. Their distribution has presented in Fig. 1.

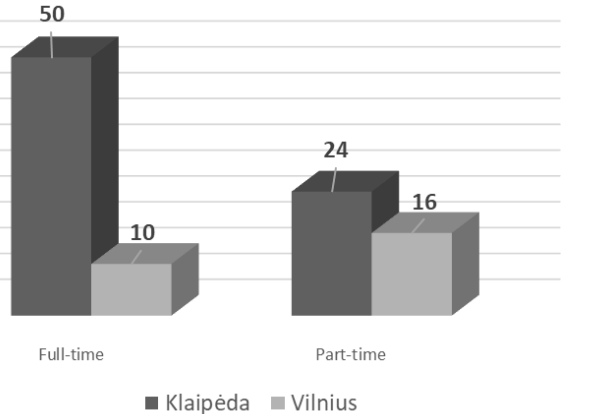

Fig. 1. Distribution of respondents by divisions and study form, $\%$

The presented distribution of respondents shows (Fig. 1) that students from continuing education form the majority of respondents. Persons who have completed secondary education in the same year of study as the reception has conducted usually select permanent studies. Consequently, interpreting the results can said of a person who has recently completed secondary education.

The table below shows (Table 1) the assessment of each of the criteria presented in the questionnaire.

Table 1. Respondents' opinion about study selection criteria

\begin{tabular}{|c|c|c|c|c|c|}
\hline Criteria & $\begin{array}{c}\text { Totally } \\
\text { agree }\end{array}$ & I agree & $\begin{array}{c}\text { Neither } \\
\text { agree nor } \\
\text { disagree }\end{array}$ & I disagree & $\begin{array}{l}\text { I totally } \\
\text { disagree }\end{array}$ \\
\hline Desire to pursue higher education & 48 & 8 & 7 & 0 & 4 \\
\hline Personal desire to develop, expand knowledge, achieve the goal & 48 & 11 & 4 & 1 & 3 \\
\hline Desire to obtain a higher education diploma & 48 & 11 & 3 & 0 & 5 \\
\hline Desire to acquire a profession & 44 & 15 & 3 & 1 & 3 \\
\hline Good career opportunities & 35 & 14 & 13 & 2 & 2 \\
\hline Better opportunities and perspectives in the work market & 31 & 21 & 11 & 2 & 2 \\
\hline Desire to find a job easier & 33 & 22 & 8 & 2 & 2 \\
\hline $\begin{array}{l}\text { Pragmatic circumstances, because it is closer to home, more } \\
\text { convenient }\end{array}$ & 9 & 7 & 18 & 11 & 20 \\
\hline Exam results & 15 & 9 & 22 & 8 & 12 \\
\hline Random selection & 10 & 8 & 13 & 11 & 25 \\
\hline Opportunity to study for free & 13 & 6 & 7 & 8 & 33 \\
\hline Encouragement of family members (parents) & 11 & 7 & 15 & 5 & 29 \\
\hline Promotion of friends and acquaintances & 9 & 5 & 15 & 7 & 31 \\
\hline Teacher counsel & 10 & 3 & 9 & 7 & 38 \\
\hline Reluctance to dismiss parents & 12 & 5 & 11 & 9 & 30 \\
\hline An attractive, interesting study program & 27 & 15 & 15 & 6 & 4 \\
\hline Good study quality & 22 & 22 & 14 & 5 & 4 \\
\hline The emergence of a new study program (specialization) & 19 & 12 & 18 & 7 & 10 \\
\hline $\begin{array}{l}\text { A more positive attitude towards colleges, a better image, goodwill } \\
\text { Fashion }\end{array}$ & $\begin{array}{c}14 \\
3\end{array}$ & $\begin{array}{c}14 \\
3\end{array}$ & $\begin{array}{l}23 \\
18\end{array}$ & $\begin{array}{l}7 \\
4\end{array}$ & $\begin{array}{c}8 \\
38\end{array}$ \\
\hline
\end{tabular}

As we can see from the data in the table (Table 1), respondents indicate three criteria that they find most important when choosing to study at a higher education institution:

- Desire to pursue higher education;

- Personal desire to develop, expand knowledge, achieve the goal;

- Desire to obtain a higher education diploma.

Totally agree with this statement $72 \%$ of respondents. Of course, these three criteria sound like this, so it can concluded that they are equally evaluated for their similarity, i.e. respondents marked their opinion with each criterion, and similarly rated the same criteria. By extending the scale of assessments and agreeing with the full acceptance of the assessment, I agree, the assessment of these criteria distributed slightly. Then another important criterion is emerging - "the desire to acquire a profession" (Fig. 2), and the criterion "the desire to pursue higher education" finds its last place. This could be because the criterion of "personal desire to develop, expand knowledge, and achieve the goal", which includes the acquisition of higher education, is also more appealing to the larger majority, but at the same time emphasizes the individual's desire for lifelong learning.

Regarding the naming of the criteria, it is clear that respondents distinguish three essential points: personal desire to improve, gaining the chosen specialty and collectively acquiring higher education. The most significant of all would be the acquisition of higher education (higher education diploma), since two criteria indicate this goal, but one of them emphasizes not only the fact of obtaining a diploma, but also the accumulated 
knowledge and skills of luggage, while the other only constitutes the acquisition of a higher education diploma the fact.

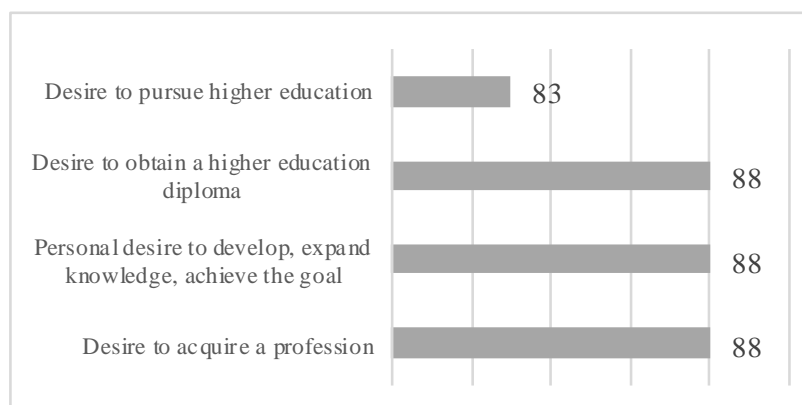

Fig. 2. The most significant evaluations of respondents, \%

In addition to the above-mentioned criteria, the quality of studies, an attractive study program, a wellorganized study process, etc., are important to respondents, but, according to respondents, they are not the most important criteria for choosing a higher education institution.

Assessing respondents' answers on the other hand, they have an opinion that they cannot really influence $(57 \%)$ other people (parents, relatives, friends or teachers). respondents indicated that their opinions were not relevant to them (Table 1).

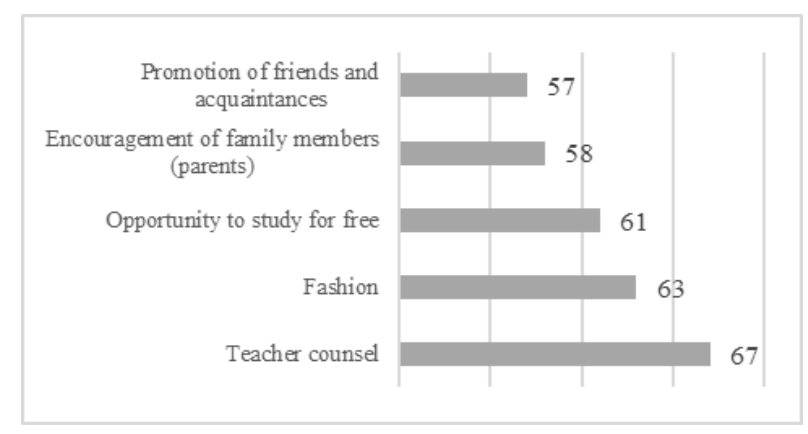

Fig. 3. Respondents' least significant estimates of claims, $\%$

Respondents also indicated that they have no significant and pragmatic circumstances, i.e. y closer to home, more comfortable. Of course, there is a large and random chance of choosing. Summarizing the minimum criterion for selecting studies, teachers' advice and fashion could be distinguished (Fig. 3).

Analysing respondents' answers in a broader context, i.e. in assessing their expectations during the study process, it can be argued that they devote considerable attention not only to the choice of study programs on demand in the work market, but also to the image of a higher education institution in society and the studying city.

\section{Conclusions}

Based on the results of the research, we can make these conclusions.
The results of the analysis of scientific literature revealed that researchers identify one the most important criteria for choosing studies. This is the prestige of higher education institution. It is very important how society assess the institution. This criterion is important in all situations and contexts when we are talking about both national and international studies in higher education.

A survey of by Lithuania Business University of Applied Sciences students showed that two factors are most important when they are choosing to study. They both were named by 88 percent of respondents each. These factors are the desire to acquire higher education and the desired specialty, as well as the personal desire to develop, expand knowledge, achieve the goal.

On the other hand, when it assesses respondents' answers, it is important to mention that other people cannot really influence students. $57 \%$ of respondents indicated that opinions of parents, relatives, friends or teachers were not relevant to them.

Research done by Lithuania Business University of Applied Sciences students who studies there, research results were similar to other Lithuanian institutions researches with says that in choice of studies in higher education institution the most important are city were person wants to study and where institution is located, higher education institution prestige and quality of the studies. The last two factors are also mentioned as the most important in international researches conducted in Finland, Hungary, Italy, Germany and other countries.

\section{References}

Aukštuolytè, N. (2011). Profesinių lūkesčių ir studijų programos pasirinkimo sąveika. Mokslinių straipsnių rinkinys „Visuomenès saugumas ir viešoji tvarka / Public security and public order. Vilnius: Mykolo Romerio universitetas, 6, p. 40-48.

Balevičiūtè, J., Valavičius, E. (2014). Vilniaus kooperacijos kolegijos studentu studiju pasirinkimo motyvai ir pasitenkinimas studijomis [revised 30 03.2020], http://alytauskolegija.lt/Dokumentai/2014/3_Baleviciute.pdf

Bereczkia, E. O., Kárpátib, A. (2018). Teachers' beliefs about creativity and its nurture: A systematic review of the recent research literature. Educational Research Review, 23, p. 2556.

Bjurulf, V. (2012). Reasons for choosing a technically oriented education: an interview study within the fields of pipefitting and industry. Int J Technol Des Educ, 22, p. 377-97.

Burkšaitienè, N. (2018). How can university learning environment contribute to students' creativity? Lithuanian students' perspective. Creativity Studies, 11 (1), p. 162 171.

Gudžinskienė, V., Railienè, A. (2012). Gyvenimo igūdžių ugdymo ir ugdymo karjerai sąsaja: bendrojo lavinimo kontekstas. Acta paedagogica Vilnensia, 29, p. $61-72$.

Hui, K., Lent, R. W. (2018). The roles of family, culture, and social cognitive variables in the career interests and goals of Asian American college students. Journal of Counseling Psychology, 65(1), 98-109.

Jovaiša, L. (2009). Profesinio orientavimo ir konsultavimo psichologija. Vilnius: Agora.

Jupiter, H., Othman, I. W., Suki, N. M., Yusoff, M. S., Awang, H.,Razak, R. A. (2017). Factors influencing international student's decision in choosing study destination abroad. Labuan e-Journal of Muamalat and Society, 11, p. 86-97.

Kardelis, K. (2016). Moksliniu tyrimu metodologija ir metodai. Vilnius: MELC. 
Katkonienè, A., Ustinavičiūtè, L., Žemaitaitytė, I. (2011). Veiksniai, susiję su sèkmingu karjeros planavimu ir profesijos pasirinkimu paauglysteje. Socialinis darbas, 10 (2), p. $169-180$.

Kirahat, S., Burananuth, N. (2018). Factors Influencing a Decision to Choose a University: A Case of Suan Sunandha Rajabhat University. Proceedings of International Academic Conferences, [revised 30 03.2020], https://ideas.repec.org/p/sek/iacpro/8810426.html

Leonavičius, V., Rutkienè, A. (2010). Aukštojo mokslo sociologija: studiju pasirinkimas ir vertinimas. Kaunas: Vytauto Didžiojo universitetas.

Lietuvos verslo kolegija (2015). Veiklos ataskaita. Klaipėda.

Lietuvos verslo kolegija (2016). Veiklos ataskaita. Klaipèda.

Lietuvos verslo kolegija (2017). Veiklos ataskaita. Klaipėda.

Lietuvos verslo kolegija (2018). Veiklos ataskaita. Klaipèda.

Lietuvos vyresniuju klasiu moksleiviu nuomonès tyrimas apie bendraji ugdyma ir studijas (2012). UAB „RAIT“, užsakius Lietuvos Respublikos švietimo ir mokslo ministerijai. [revised $30 \quad$ 03.2020], http://www.smm.lt/uploads/documents/kiti/Rait_SMM_201 20329.pdf

Liobikienè, L., Bukauskienė, L. (2014). Jaunuolių vertybių ir profesijos pasirinkimo sąveika. Profesinis rengimas: tyrimai ir realijos, 25 , p. $98-108$.

Liubinienè, D., Slimavičienè, A. (2016). Studiju pasirinkima $\begin{array}{llll}\text { lemiantys veiksniai [revised } 30 & 03.2020],\end{array}$ http://ojs.kaunokolegija.lt/index.php/mttlk/article/viewFile/4 $8 / 54 /$
Petruzzellis, L., Romanazzi, S. (2010). Educational value: How students choose university: Evidence from an Italian university. International Journal of Educational Management, 24, p. 139-158.

Rodd, M., Reiss, M., Mujtaba, T. (2014). Qualified, But Not Choosing STEM at University: Unconscious Influences on Choice of Study. Canadian Journal of Science, Mathematics and Technology Education, 14 (4), p. 330 345.

Romeryte-Šereikienè, R., Šaltytè-Vaisiauskè, L. (2019). Study of the LBUAS graduates career monitoring. Journal of Management, 35 (2), p. 67-70.

Statnické, G., Čeledinaite, A. (2018). Career Management Opportunities of Generation Y: a Sports Manager Case Study. Journal of Management, 33 (2), p. 15-22.

Studiju pasirinkimo motyvai ir pasirengimas studijoms. (2014). Mokslo ir studijų stebėsenos ir analizès centras (MOSTA). [revised 30 03.2020], http://www.mosta.lt/images/leidiniai/ Studiju_pasirinkimo_motyvai_TRUMPRASTIS.pdf

Urboniene, L. (2015). Studiju programos pasirinkimas kaip sékmingos karjeros prielaida [revised 30 03.2020], https://svako.lt/uploads/pstp-15-2015-19.pdf

Wilkins, S., Balakrishnan, M. S., Huisman, J. (2012). Student Choice in Higher Education: Motivations for Choosing to Study at an International Branch Campus. Journal of Studies in International Education, 16 (5), p. 413-433.

Rasa Grigolienė. PhD in Physical Sciences (Mathematics), associated professor at Lithuania Business University of Applied Sciences and Klaipeda University. Area of scientific research is applied statistics and mathematical modelling; area of professional interest is systems of higher education, quality of studies in higher school. Publications: 28 scientific papers and 7 handbooks. Address: H. Manto Street 84, Klaipėda, Lithuania. Phone: +370 463989 34. E-mail: rasa.grigoliene@ku.lt or rasa.grigoliene@1tvk.lt

Raimonda Tamoševičienė. MSc in Management, associated professor at Lithuania Business University of Applied Sciences. Area of scientific research is business language, public communication, career planning, coaching. Address Turgaus Street 21 , Klaipeda, Lithuania. Phone +370 463110 99. E-mail: raimonda.tamoseviciene @ ltvk.lt 